\title{
Reduction of Production Costs in Agribusiness Companies in the Western Region of the State of Paraná Using Photovoltaic Systems Connected to the Grid
}

\author{
Mario Elias Carvalho do Nascimento ${ }^{1}$, Jair Antonio Cruz Siqueira ${ }^{1}$, Carlos Eduardo Camargo Nogueira ${ }^{1}$, \\ Maritane Prior ${ }^{1} \&$ Mauricio Guy de Andrade ${ }^{2}$ \\ ${ }^{1}$ Post-graduation in Energy Engineering in Agriculture, Western Paraná State University, Cascavel, Paraná, \\ Brazil \\ ${ }^{2}$ Agriculture Engineering, Federal University of Paraná, Palotina, Paraná, Brazil \\ Correspondence: Mario Elias Carvalho do Nascimento, Post-graduation in Energy Engineering in Agriculture, \\ State University of Western Paraná, Cascavel, Paraná, Brazil. Tel: 55-459-9101-2122. E-mail: \\ marioelias_carvalho@yahoo.com
}

Received: March 31, 2019

Accepted: May 1, 2019

Online Published: June 30, 2019

doi:10.5539/jas.v11n9p198

URL: https://doi.org/10.5539/jas.v11n9p198

\begin{abstract}
This investigation was a case study of designs for grid-tie photovoltaic systems in agribusiness enterprises in the western region of the state of Paraná, in Brazil. Electricity consumption data of three grain storage enterprises and a complex with three aviaries was studied. Their monthly electricity consumption and production costs data were collected, and solar radiation data for the same locations were collected from the SunData database. Indices that related electricity costs and production expenses, and the photovoltaic system costs and production expenses were developed. The indices showed to be efficient tools of cost relation for systems of different installed powers and different agricultural productions. The study showed a cost reduction in production of up to $62.71 \%$ for the aviaries, and $76.87 \%$ for the grain storage enterprises, concluding that the use of grid-tie photovoltaic systems reduces the cost of production and increases the profit of the enterprises.
\end{abstract}

Keywords: grid-tie photovoltaic systems, agribusiness, aviaries, grain storage enterprises, cost reduction

\section{Introduction}

Brazil ranks third in corn production, with $9.12 \%$ of the world production; first in coffee, with $32.02 \%$; and first in soybean, with $67.82 \%$. Other highlights are: the leading orange juice and fresh oranges producer, with $66.46 \%$ and $35.19 \%$ of the world production, respectively; and in fourth position when it comes to sugar, soybean meal, soybean oil, and cottonseed production (FAS, 2018).

Brazil it is the second largest exporter of agricultural products to the European Union (Hubbard et al., 2017). For instance, exportation to the European Union in the year 2015/2016 generated US\$18.3 billion (Alan Bojanic, 2017). According to the Ministry of Agriculture, Livestock and Food Supply, in the year 2015/2016, Brazil exported goods totaling US\$52.9 billion, with the main markets being China, the European Union, the United States, Japan, Russia, and Saudi Arabia.

According to the National Energy Balance of 2018, the agricultural sector presented electricity consumption of 2 470000 toe. In 2010, it was 1629000 toe, resulting, therefore, in an increase of 51.62\% in seven years (EPE, 2018).

The solution of electricity generation through grid-tie photovoltaic systems is believed to be feasible in its implementation for some reasons: a) ease of project development, since the equipment for electric energy generation were all modular, thus facilitating implementation (Savazzi \& Sobrinho, 2017); b) the small and micro rural producers or entrepreneurs of the agribusiness sector would not depend on the electric power transmission network and the logistics of the electric power supply companies (Priester et al., 2017), c) the environmental impact would be minimal, since it is a clean and renewable source (Lo \& Mayumi, 2017), d) the project's financial return is short-term, in theory, depending on the size of the installed PV system (De Castro et 
al., 2016); and e) there is the government's interest in implementing this type of systems, providing attractive funding lines and amortization time (Griebeler et al., 2016).

The hypothesis raised was that the greater the installed power of the grid-tie photovoltaic system, the greater the economic efficiency in agricultural production, thus increasing the profitability of the agribusiness enterprise.

\section{Method}

The work was developed in the state of Paraná, with its geographical coordinates S $24^{\circ} 57^{\prime} 21^{\prime \prime}$ and W 51 $27^{\prime} 19^{\prime \prime}$, located in the southern region of Brazil. The region's climate can be classified as subtropical (Köppen \& Geiger, 1928), and it presents an annual average solar radiation of $5.44 \mathrm{kWh} \mathrm{m}^{-2}$ (Tiepolo et al, 2017).

The agribusiness enterprises will be divided into two economic sectors: aviaries for broiler chickens and grain storage silos.

\subsection{Aviaries}

Average annual radiation of $4.83 \mathrm{kWh} \mathrm{m}^{-2}$ (CRESESB, 2018). The electric energy consumption was studied from November 2016 to January 2018, totaling $167603 \mathrm{kWh}$, and the cost of R $\$ 45562.87$, with a capacity of 25000 heads of chicken per batch, and 515550 of them received during the period.

\subsection{Small Silo}

Average annual radiation of $4.70 \mathrm{kWh} \mathrm{m}^{-2}$ (CRESESB, 2018). The electric energy consumption was studied from June 2017 to May 2018, totaling $40045 \mathrm{kWh}$, and a cost of R\$17388.86. There is a silo of 2000 tons and four hoppers with 72 tons each, totaling a storage capacity of 2288 tons.

\subsection{Medium Silo}

Average annual radiation of $4.81 \mathrm{kWh} \mathrm{m}^{-2}$ (CRESESB, 2018). The electric energy consumption was studied from July 2017 to June 2018, totaling $145802 \mathrm{kWh}$, and a cost of R\$ 61275.67 . There are two silos of 1800 tons each, a lung silo of 1800 tons, and four hoppers with 150 tons each, totaling a storage capacity of 6000 tons.

\subsection{Large Silo}

Average annual radiation of $4.74 \mathrm{kWh} \mathrm{m}^{-2}$ (CRESESB, 2018). The electric energy consumption was studied from July 2017 to July 2018, totaling $593190 \mathrm{kWh}$, and a cost of R $\$ 257804.88$. There are eight silos of 4500 tons each, four lung silos of 600 tons each, a bulk carrier with 10000 tons, and four hoppers with 240 tons each, totaling 49 360 tons.

\subsection{Dimensioning Grid-Tie Photovoltaic Systems}

\subsubsection{Peak Power of the Photovoltaic System}

The $\mathrm{kWp}$ was calculated using Equation 1, the average daily consumption, and the average annual monthly radiation of the enterprise location, by sizing the power generated per day (Pinho \& Galdino, 2014).

$$
S_{w p}=(E / F S H)
$$

Where, Swp: the photovoltaic system's peak power (Wp); E: the average annual daily consumption $\left(\mathrm{kWh} \mathrm{day}^{-1}\right)$; FSH: Full Sun Hours annual average $\left(\mathrm{kWh} \mathrm{m}^{2} \mathrm{day}^{-1}\right)$.

\subsubsection{Generation of Electricity at the End of the System's Useful Life}

The photovoltaic system was calculated to generate the amount of electric energy to the 25 years of useful life. The solution of Equation 1 was used and it was divided by the decrease of $20 \%$ of generation the system suffers at the end of the useful life, as demonstrated by Equation 2 (Pinho \& Galdino, 2014).

$$
E_{\text {real }}=(E / 0.80)
$$

\subsubsection{Number of Photovoltaic Modules}

The number of photovoltaic modules is the ratio between the photovoltaic system's power, the chosen photovoltaic module's power, and the photovoltaic system's real installed power, calculated using Equation 3 (Pinho \& Galdino, 2014).

$$
N_{m}=\left(E_{\text {real }} / P_{m}\right)
$$

Where, $\mathrm{N}_{\mathrm{m}}$ : the number of modules (dimensionless); $\mathrm{E}_{\text {real }}$ : the real average annual daily consumption $\left(\mathrm{kWh} \mathrm{day}^{-1}\right)$; $\mathrm{P}_{\mathrm{m}}$ : the module's power $(\mathrm{W})$. 


\subsubsection{Maximum Number of Photovoltaic Modules by Inverter}

Calculated using Equation 4, the maximum load of photovoltaic modules per inverter took into account a load range of $10 \%$ of the inverter's power (Pinho \& Galdino, 2014).

$$
M_{n m}=\left(P_{i n v} / P_{m}\right)
$$

Where, $\mathrm{M}_{\mathrm{nm}}$ : the maximum number of modules (dimensionless); $\mathrm{P}_{\mathrm{inv}}$ : the inverter's power $(\mathrm{W}) ; \mathrm{P}_{\mathrm{m}}$ : the module's power (W).

\subsubsection{Maximum Number of Modules by MPPT and Mumber of Strings in Parallel}

The maximum number of modules by Maximum Power Point Tracking (MPPT) was calculated using Equation 5. And the number of strings in parallel by MPPT input was calculated through Equation 6 (Pinho \& Galdino, 2014).

$$
\left(M_{v i} / M_{v}\right) \leq M_{n m m p p t} \leq\left(M_{v m i} / M_{v}\right)
$$

Where, Mvi: the inverter's minimum voltage (V); Mv: the module's voltage (V); Mvmi: the inverter's maximum voltage $(V) ; \mathrm{M}_{\text {nmmppt }}$ the maximum number by MPPT (dimensionless).

$$
N_{p s}=\left(I_{m i} / I_{m p}\right)
$$

Where, $\mathrm{N}_{\mathrm{ps}}$ : the number of pararell strings by MPPT (dimensionless); $\mathrm{I}_{\mathrm{mi}}$ : the inverter's maximum current (A); $\mathrm{I}_{\mathrm{mp}}$ : the operating current $(\mathrm{A})$.

The components of the photovoltaic system available in the domestic market were used. A survey in the market was made, and it was opted for the photovoltaic module and the Canadian Solar ${ }^{\circ}$ inverters, module model CS6U-330P, which costs R $\$ 689.00$; inverter CSI-50k-KLT of $50000 \mathrm{~W}$ of power, R $\$ 32590.00$; and CSI-30k-KLT of $30000 \mathrm{~W}$ of power, R $\$ 22590.00$.

The Stringbox NeoSolar ${ }^{\circledR}$ was chosen for the protection part, Stringbox Pro $4 \times 2$ model, which has the following characteristics: support to four input strings, two outputs, IP65 frame, two 3P switch disconnector 25A 1000Vcc, two surge protectors PV SCI $1000 \mathrm{Vdc}$, and two surge protection systems (DPS) CC FV 1000V, costing R $\$ 1$ 700.00 .

For fixation of the photovoltaic modules with $2 \mathrm{~m}, 0.99 \mathrm{~m}$ and $0.035 \mathrm{~m}$ height, width and length, respectively, soil structures were used. Due to the area the systems required for the installation, the cost of the structure was $\mathrm{R} \$ 749.00$, being possible to install up to four modules per structure.

Other costs of civil structure and grounding in the design of the photovoltaic system were disregarded, since the specialized companies did not respond to the budget requests in time.

\section{Results and Discussion}

The electric power consumption of the enterprises and Equations 1,2 and 3 were used for the sizing of the installed power of the grid-tie photovoltaic systems, as shown in Table 1.

Table 1. Sizing of the photovoltaic systems' installed power

\begin{tabular}{lllll}
\hline Enterprises & Electric Power Consumption & Equation 1 & Equation 2 & Equation 3 \\
\hline Aviaries & $167603 \mathrm{kWh}$ & $77.11 \mathrm{kWp} \mathrm{day}^{-1}$ & $96.38 \mathrm{kWp} \mathrm{day}^{-1}$ & 292 modules \\
Small Silo & $40045 \mathrm{kWh}$ & $23.66 \mathrm{kWp} \mathrm{day}^{-1}$ & $29.58 \mathrm{kWp} \mathrm{day}^{-1}$ & 92 modules \\
Medium Silo & $145802 \mathrm{kWh}$ & $84.20 \mathrm{kWp} \mathrm{day}^{-1}$ & $105.25 \mathrm{kWp} \mathrm{day}^{-1}$ & 318 modules \\
Large Silo & $593190 \mathrm{kWh}$ & $320.88 \mathrm{kWp} \mathrm{day}^{-1}$ & $401.11 \mathrm{kWp} \mathrm{day}^{-1}$ & 1216 modules \\
\hline
\end{tabular}

The required photovoltaic systems' installed power was used. The costs of the equipment required for each system were verified. The equipment was surveyed in the domestic market, and the final cost of the enterprises was obtained and shown in Table 2. 
Table 2. Cost of photovoltaic systems per enterprise

\begin{tabular}{|c|c|c|c|c|c|}
\hline Equipment & Cost $(\mathrm{R} \$)$ & $\begin{array}{l}\text { Aviary } \\
(96.38 \mathrm{~kW})\end{array}$ & $\begin{array}{l}\text { Small Silo } \\
(29.58 \mathrm{~kW})\end{array}$ & $\begin{array}{l}\text { Medium Silo } \\
(105.25 \mathrm{~kW})\end{array}$ & $\begin{array}{l}\text { Large Silo } \\
(401.11 \mathrm{~kW})\end{array}$ \\
\hline CS6U-330P & 689.00 & 292 & 92 & 318 & 1,216 \\
\hline CSI-50k-KLT & 32590.00 & 2 & - & 2 & 8 \\
\hline CSI-30k-KLT & 22590.00 & - & 1 & - & - \\
\hline StringBox & 1700.00 & 4 & 2 & 4 & 16 \\
\hline $\mathrm{CC} 10 \mathrm{~mm}^{2}(\mathrm{~m})$ & 14.00 & 800 & 400 & 800 & 1500 \\
\hline \multirow[t]{2}{*}{ Ground fixing structure (unit) } & 749.00 & 73 & 23 & 80 & 304 \\
\hline & Total $(R \$)$ & 339045.00 & 112205.00 & 362202.00 & 1374440.00 \\
\hline
\end{tabular}

The aviary complex consists of three aviaries, each with the capacity of 25000 heads of chicken per batch, and it receives 5.5 batches per year, totaling 412500 heads of chicken per year. During the study period, there were 515550 heads of chicken, and the electric energy consumed was $167603 \mathrm{kWh}$, with the cost of R\$45 562.87 .

The first index related the amount of energy per chicken head. The result was $0.325 \mathrm{kWh}$ of energy consumed per head. The second index related the cost of the energy consumed per head of chicken and resulted in the cost of $\mathrm{R} \$ 0.0885$ per head. The third index related the cost of the annual photovoltaic system, which was $\mathrm{R} \$ 13$ 651.80 , being that in the same study period the cost of the system was $\mathrm{R} \$ 17042.25$ for the amount of chicken heads per year, and the cost of $\mathrm{R} \$ 0.033$ per head was obtained.

In the small silo, in the study period, from June 2017 to July 2018, there were 1696.026 tons of stored soybean, and 6 tons of corn. The quantity of grains of one variety was much higher than the other, thus the totality was considered to be only of soybean.

The cost of electricity consumed off-peak was $\mathrm{R} \$ 17388.86$, the total energy was $40045 \mathrm{kWh}$, and 1702026 tons of soybean were stored. It was obtained an index that related: the energy consumed by the quantity of stored grains, which was $23.53 \mathrm{kWh} \mathrm{ton}^{-1}$; and the cost of energy consumed off-peak per tons of grain, totaling $\mathrm{R} \$ 10$ 216.ton ${ }^{-1}$. In addition, the annualized cost of the photovoltaic system was divided by the amount of stored grains, generating the index of R $\$ 2637$ ton $^{-1}$.

The average silo stored 949157 tons of soybean and 1430780 tons of maize during the study period, from July 2017 to June 2018, totaling 2379.94 tons of grains.

The cost to the electric energy consumed off-peak was R $\$ 61275.65$, and the total energy was $145802 \mathrm{kWh}$. It was obtained an index that related: the energy consumed by the quantity of stored grains, which was $61.26 \mathrm{kWh}$ ton $^{-1}$; and the cost of energy consumed off-peak per tons of grain, totaling R $\$ 25746$ ton $^{-1}$. In addition, the annualized cost of the photovoltaic system was divided by the amount of grains stored, generating the index of $\mathrm{R} \$ 6087$ ton $^{-1}$.

The large silo for large sized-grains stored 31081 tons of soybean, 23991262 tons of corn, and 4130382 tons of wheat, during the study period, from July 2017 to July 2018, totaling 59202.64 tons of grains.

The cost to the electric energy consumed out of tip was of $\mathrm{R} \$ 257804.88$, and the total energy was of 593190 $\mathrm{kWh}$. It was obtained an index that related: the energy consumed per ton of grain stored, which was $10.01 \mathrm{kWh}$ ton $^{-1}$; and the cost of energy consumed off-peak per tons of grain, totaling $\mathrm{R} \$ 4.35 \mathrm{ton}^{-1}$. In addition, the annualized cost of the photovoltaic system was divided by the number of grains stored, generating the index of $\mathrm{R} \$ 1006 \cdot \mathrm{ton}^{-1}$.

Through the indexes, it was verified that the photovoltaic systems helped to reduce the costs of production. It was observed that for the complex of three aviaries the costs of production in relation to electric energy went from $\mathrm{R} \$ 0.0885$ to $\mathrm{R} \$ 0.033$ per head of chicken. In the grain storage enterprises, it went from $\mathrm{R} \$ 10.216$ to $\mathrm{R} \$ 2.637$ per ton of grain stored for the small silo, from $\mathrm{R} \$ 25.476$ to $\mathrm{R} \$ 6.087$ in the medium silo, and from $\mathrm{R} \$ 4.35$ to $\mathrm{R} \$ 1.006$ in the large silo.

\section{Conclusion}

It was concluded that the reduction in cost of production is related to the rate charged by the electric energy consumed, since for the complex of three aviaries that has a rate of $\mathrm{R} \$ 0.272$, the reduction was of $62.71 \%$, and for the grains storage enterprises that have rates of $\mathrm{R} \$ 0,434, \mathrm{R} \$ 0,420$ and $\mathrm{R} \$ 0,434$, reductions were of $75.79 \%$, $76.35 \%$, and $76.87 \%$, for the small, medium and large silo storage enterprises, respectively. 
It was also concluded that the reduction in cost of production has a linear relationship: the greater the sizing of the photovoltaic system, the greater the reduction in the cost of production, when the enterprises have the same electric energy rate.

\section{References}

Alan Bojanic, H. (2017). The Rapid Agricultural Development of Brazil in the Last 20 Years. EuroChoices, 16, 5-10. https://doi.org/10.1111/1746-692X.12143

CRESESB. (2018). SunData. Retrieved from http://www.cresesb.cepel.br/index.php?section=sundata\&

Dallepiane, P., Santos, G., \& Rodrigues, M. (2014). A Geração de Energia Elétrica Com Biogás Para Atender Agroindústrias, Proteger Meio Ambiente E Melhorar Fornecimento De Energia No Meio Rural. Rev. Interdiscip. Ensino, Pesqui. e Extrensão, 3, 163-175.

De Castro, N., Brandão, R., Rosental, R., \& Dorado, P. (2016). Brazil and the International Electrical Integration: Background, Current Status and Perspectives. Energy Procedia, 106, 204-214. https://doi.org/10.1016/ j.egypro.2016.12.116

EPE (Empresa de Pesquisa Energética). (2017). Balanço Energético Nacional. Empresa de Pesquisa Energética.

FAS (Foreign Agricultural Service). (2018). PS\&D-Production, Supply and Distribution [WWW Document]. United States Dep. Agric. Retrieved from https://apps.fas.usda.gov/psdonline/app/index.html\#/app/home/ statsByCountry

Griebeler, D. I., Corassini, L. B., Castro, S. da S., Ribeiro, K. M., Ceretta, F. C. da C., \& Cruz, A.C. da (2016). Análise para Implantação de Sistema Fotovoltaico de Geração de Energia em uma Agroindústria de Santo Cristo/RS (pp. 1-12). $1^{\text {a }}$ Conferência Internacional de Sustentabilidade e Inovação, Santa Maria.

Hubbard, C., Alvim, A. M., \& Garrod, G. (2017). Brazilian Agriculture as a Global Player. EuroChoices, 16, 3-4. https://doi.org/10.1111/1746-692X.12142

Köppen, W., \& Geiger, R. (1928). Klimate der Erde. Gotha: Verlag Justus Perthes.

Lo, S., \& Mayumi, K. (2017). Toward an integrated assessment of the performance of photovoltaic power stations for electricity generation. Appl. Energy, 186, 167-174. https://doi.org/10.1016/j.apenergy.2016. 05.102

Nadir, I., Vilela, R., \& Peres, E. (2016). Análise Do Mercado Potencial Da Geração Distribuída Fotovoltaica No Brasil (pp. 1-6).

Pinho, J. T., \& Galdino, M. A. (2014). Manual De Engenharia Para Sistemas Fotovoltaicos (2nd ed.). Cepel, Cresesb, Rio de Janeiro. https://doi.org/10.3329/bjpt.v22i2.26075

Priester, A. L., Moscardi, S. C., Possenti, M. A., \& Migliorini, E. (2017). Análise de Despesas Relacionadas à Energia Elétrica de Propriedades Produtoras de Frango de Corte da Região do Sudoeste do Paraná (pp. 283-285). IV Congresso de Ciencia e Tecnologia Da UTFPR-DV. UTFPR, Dois Vizinhos.

Savazzi, É. R., \& Sobrinho, P. M. (2017). Oportunidades para Expansão da Cogeração de Eletricidade para o Sistema Interligado Nacional (pp. 1-10). The 12th Latin-American Congress on Electricity Generation and Transmission-Clagtee 2017. São Paulo.

Tiepolo, G. M., Pereira, E. B., Urbanetz Jr, J., Pereira, S. V., Goncalves, A. R., Lima, F. J. L., ... Alves, A. R. (2017). Atlas Solar do Paraná [WWW Document]. Univ. Tecnol. Fed. do Paraná. Retrieved from http://atlassolarparana.com

Vale, A. M., Felix, D. G., Fortes, M. Z., Borba, B. S. M. C., Dias, B. H., \& Santelli, B. S. (2017). Analysis of the economic viability of a photovoltaic generation project applied to the Brazilian housing program "Minha Casa Minha Vida". Energy Policy, 108, 292-298. https://doi.org/10.1016/j.enpol.2017.06.001

\section{Copyrights}

Copyright for this article is retained by the author(s), with first publication rights granted to the journal.

This is an open-access article distributed under the terms and conditions of the Creative Commons Attribution license (http://creativecommons.org/licenses/by/4.0/). 